\title{
Can inhibition or shifting training enhance cognitive abilities in emerging adults?
}

\author{
Anja Podlesek ${ }^{1^{*}}$, Marina Martinčević ${ }^{2}$ and Andrea Vranić 2 \\ ${ }^{1}$ Department of Psychology, Faculty of Arts, University of Ljubljana, Slovenia \\ ${ }^{2}$ Department of Psychology, Faculty of Humanities and Social Sciences, University of Zagreb, Croatia
}

\begin{abstract}
Executive functions enable and support most of our daily cognitive functioning. Within the number of executive functions proposed, updating, inhibition and shifting are most often considered as the three core executive functions. Cognitive training paradigms provide a platform for a possible enhancement of these functions. Since updating training has been studied to a greater extent, we wanted to investigate the effectiveness of inhibition and shifting training in this study. Emerging adults (psychology students) were randomly assigned either to the inhibition training (based on the Simon task; $n=36$ ) or to the shifting training (based on the task switching paradigm; $n=35$ ). Both groups underwent twelve 20-minute sessions distributed over four weeks. Measurements before and after the training included criterion tasks (i.e. the training tasks), near-transfer tasks (i.e. tasks that address the trained functions but use different types of stimuli or rules to respond), and far-transfer tasks (i.e., tasks that address untrained cognitive functions). The control participants $(n=36)$ were tested with a combination of these tasks. Both training groups improved their criteria task performance over time, while convincing training-related gains were not found in either near- or far-transfer tasks. This study raises some conceptual questions for the training of executive functions with respect to a sample of emerging adults with above-average cognitive abilities, motivational elements of training, and the role of executive functions in more complex everyday cognitive activities.
\end{abstract}

Keywords: cognitive training, executive functions, inhibition, shifting

\section{Ali lahko vadba inhibicije ali preklapljanja izboljša kognitivne sposobnosti mladih na prehodu v odraslost?}

\author{
Anja Podlesek ${ }^{1 *}$, Marina Martinčević 2 in Andrea Vranić ${ }^{2}$ \\ ${ }^{1}$ Department of Psychology, Faculty of Arts, University of Ljubljana, Slovenia \\ ${ }^{2}$ Department of Psychology, Faculty of Humanities and Social Sciences, University of Zagreb, Croatia
}

Povzetek: Izvršilne funkcije omogočajo in podpirajo večino našega vsakdanjega kognitivnega delovanja. Med številnimi izvršilnimi funkcijami raziskovalci najpogosteje kot tri najbolj osnovne opredeljujejo posodabljanje informacij, inhibicijo in preklapljanje. Paradigme kognitivnega treninga predstavljajo način njihovega izboljševanja. Učinkovitost treninga posodabljanja informacij je že precej raziskana, v pričujoči raziskavi pa smo želele preučiti učinkovitost treningov inhibicije in preklapljanja. Mlade na prehodu v odraslost (študente psihologije) smo naključno razdelile v skupino, ki je z izvajanjem Simonove naloge trenirala inhibicijo $(n=36)$, in skupino, ki je s paradigmo preklapljanja med nalogami trenirala preklapljanje $(n=35)$. Obe skupini sta skozi štiri tedne izvedli dvanajst 20-minutnih treningov. Predtestna in naknadna merjenja so poleg kriterijskih, tj. treniranih nalog vključevala še naloge bližnjega transfera ( $\mathrm{tj}$. naloge, ki vključujejo trenirano funkcijo, a uporabljajo drugačne vrste dražljajev ali pravil odzivanja) in naloge daljnega transfera ( $\mathrm{tj}$. naloge, ki vključujejo netrenirane kognitivne funkcije). Nekatere od nalog je reševala tudi kontrolna skupina $(n=36)$. Pri obeh skupinah s treningom se je v času izboljšala učinkovitost reševanja kriterijske naloge, pri nalogah bližnjega in daljnega transfera pa ni bilo opaziti prepričljivega izboljšanja, ki bi ga lahko pripisali izključno treningu. Raziskava je opozorila na konceptualne težave treniranja izvršilnih funkcij, vezane na vzorec mladih nadpovprečno kognitivno sposobnih odraslih, motivacijske elemente treninga in vlogo izvršilnih funkcij v zahtevnih vsakodnevnih aktivnostih.

Ključne besede: kognitivni trening, izvršilne funkcije, inhibicija, preklapljanje

\footnotetext{
"Naslov/Address: dr. Anja Podlesek, Department of Psychology, Faculty of Arts, University of Ljubljana, Aškerčeva 2, 1000 Ljubljana, Slovenia, e-mail: anja.podlesek@ff.uni-lj.si
}

Članek je licenciran pod pogoji Creative Commons Attribution 4.0 International licence. (CC-BY licenca).

The article is licensed under a Creative Commons Attribution 4.0 International License (CC-BY license). 
Executive functions (EF) are among the most important cognitive functions needed for regular day-to-day functioning. Early studies mainly considered EF in clinical populations, but today EF are increasingly being studied in people with normal cognitive functioning. EF can be defined as processes that control and regulate human thought and action and are often associated with frontal lobe functioning (Friedman et al., 2006). According to Miyake et al. (2000), there are three core EF: updating, inhibition and shifting. These core functions form a constitutive part of higher-order functions such as reasoning, problem solving, and planning (Diamond, 2013).

One way we can enhance EF is by implementing cognitive trainings. Cognitive trainings are interventions in form of structured practice on tasks relevant to various aspects of cognitive functioning (Martin et al., 2011). EF trainings are designed to enhance $\mathrm{EF}$, consequently enhancing more complex cognitive functions. A large number of papers have investigated the effects of EF trainings, with most of them focusing on updating training (e.g., De Simoni \& von Bastian, 2018; Zuber et al., 2016). Inhibition and shifting training have been less studied. Therefore, in this study, we investigated the effectiveness of inhibition and shifting training for emerging adults.

\section{Executive functions}

EF represent a set of higher level cognitive processes that influence lower level processing and enable engagement in independent, purposive and self-directed behaviour (Friedman \& Miyake, 2017). The construct was first described by Baddeley and Hitch (1974) in their working memory (WM) model as a central executive component. Even though the central executive was the most important component in this model, other components were investigated more, while the central executive remained unexplored for many years (Baddeley, 2007).

An important paper contributing to the new understanding of EF is the study of Miyake and colleagues (2000). Among a number of EF discussed in the literature (e.g., planning, initiation and monitoring the actions, utilization of feedback; Chan et al., 2008), they have identified updating, shifting and inhibition as main EF. Updating refers to the process of monitoring WM content and representation, i.e., tracking of new and upcoming information and the corresponding modification of WM content (Smith \& Jonides, 1997). Shifting refers to altering back and forth between multiple tasks or mental sets (Monsell, 1996). It enables successful disengagement with an irrelevant task set and adequate performance despite proactive interference or priming (Miyake et al., 2000). Inhibition refers to controlled suppression of dominant or automatic response when another response is required. These EF represent separable but moderately correlated constructs which provide differential contribution to one's performance on more complex executive tasks (e.g., Wisconcin Card Sorting Test, Tower of Hanoi) used in cognitive and neuropsychological research (Miyake et al., 2000).
New insights into EF have led to their incorporation into some contemporary WM models (e.g., Baddeley, 2007). Even though different WM models do not always agree on the core set of EF, most of them include inhibition, shifting and updating (e.g., Baddeley, 2007; Cowan, 2005). The rationale for inclusion of these functions into WM models is derived from many studies which show significant associations between WM and EF (e.g., Unsworth \& Spillers, 2010; Wongupparaj et al., 2015).

In addition to $\mathrm{WM}, \mathrm{EF}$ also play an important role in cognitive processes required for normal daily functioning. One of them is prospective memory (PM) which is defined as an ability to execute an intention at the specific time or event in the future, such as taking medication after lunch (Ellis \& Kvavilashvili, 2000). PM has often been used as a measure of daily functioning due to its importance in coordinating cognitive functions required to perform many real-world activities (Ellis \& Kvavilashvili, 2000). It includes shaping and directing cognition to future actions and plans, hence its importance in everyday functioning. According to the Multiprocess Framework (McDaniel \& Einstein, 2000), inhibition and shifting are crucial for the performance in the PM tasks. When PM task is immersed in an ongoing task, participants have to inhibit dominant response to the ongoing task and perform a PM action. On the other hand, when the PM task does not form a part of an ongoing task, participants rely more on the shifting ability, thus switching between solving the ongoing task and checking the environment for PM cues (Zuber et al., 2016). Studies show a significant proportion of shared variance between EF and PM $(r=.74$ in Salthouse et al., 2004), which was confirmed by neuropsychological studies showing overlap of prefrontal brain activity for PM and EF tasks (McDaniel et al., 1999). More specifically, studies show significant association between focal PM task and inhibition, and non-focal PM task and shifting (e.g., Kliegel et al., 2003; Zuber et al., 2016, 2019). Unlike inhibition and shifting, the relationship between updating and PM is rarely found (Schnitzspahn et al., 2013).

\section{EF training}

Because of the importance of EF for complex cognitive activities, such as WM and PM, enhancement of EF has become an interesting topic in the field of cognitive training in recent years. The efficacy of training lies in learning of new strategies for efficient task solving, or in extensive exercise of specific cognitive processes. Training efficacy is considered not only in terms of the ability central to the training, but also the ability to transfer training-related skills to other nontrained tasks. In this sense, we distinguish between near and far transfers (Barnett \& Ceci, 2002). Near transfer refers to the ability to improve performance in tasks that have a similar structure and activate same cognitive functions or processes as the trained task, while far transfer involves enhanced performance in untrained tasks and domains that are less related to the trained ability. Studies usually confirm near transfer, but evidence of far transfer is scarce and effects can be very small (Karbach \& Verhaeghen, 2014). An important 
factor related to transfer effects is participants' age. Due to the greater brain plasticity, younger participants usually show greater gains in trained tasks and wider transfer effects (Dahlin et al., 2008).

Two main approaches to EF enhancement are multimodal trainings and process-based trainings (Lustig et al., 2009). While multimodal trainings are complex interventions in which two or more cognitive processes are enhanced, process trainings are a type of cognitive drill. They appear to be particularly suitable for EF training (Lustig et al., 2009). Within the process-based approach to training, updating is the most commonly explored EF. Updating trainings usually show positive effects on trained abilities and complex measures of WM in different populations (e.g., Melby-Lervåg et al., 2016). Effects on other cognitive abilities, such as fluid reasoning, are still under debate; some studies confirm the transfer effects (e.g., Au et al., 2015), while others do not (De Simoni \& von Bastian, 2018). Although updating has often been explored, other EF - inhibition and shifting - have received less attention when it comes to cognitive trainings. The reasons for this might lie in the notion that inhibition is an "untrainable" ability (Berkman et al., 2014).

Inhibition trainings in children and healthy adults show positive effects on the trained ability. However, a few studies which have explored its transfer did not confirm the transfer to other cognitive abilities (e.g., Dowsett \& Livesey, 2000; Thorell et al., 2009). Inhibition training is more often employed in clinical populations. These studies show promising effects of the training on inhibition-related behaviors, such as controlling food intake (Houben, 2011) or reducing alcohol consumption (Houben et al., 2011). Even though inhibition training studies do not always show effects on behavioral measures, this does not mean that there are no structural or functional changes in the brain during the training. Berkman and colleagues (2014) have conducted inhibition training study featuring neuroimaging of training effects, which has shown changes in neural activation in the inferior frontal gyrus during the preparation (cue) and implementation (stopping) phase after 10 sessions of training. Therefore, higher-dosage inhibition training might enable the showing of training in behavioral measures.

Shifting trainings usually use task switching paradigms in which participants must switch between two simple tasks, such as adding a number on one trial and then subtracting it on the next trial. Trials that involve task switching result in slower reaction time (RT) compared to trials with a repeated task (Wylie et al., 2004). These tasks activate not only the prefrontal cortex, but also the parietal lobe (De Baene et al., 2012). Broad brain area activation might lead to greater transfer effects via functional or structural enhancement of areas tapping multiple cognitive functions. Existing research confirms promising training effects (e.g. Kray \& Ferdinand, 2014). For example, Karbach \& Kray (2009) found that shifting training has enhanced performance not only on similar tasks, but also on inhibition, WM, and fluid reasoning tasks in children, young and older adults. This pattern of results indicating near and far transfer effects have been confirmed in other studies that have used other measures (e.g., Gaál \& Czigler, 2018) or have been conducted with clinical populations (e.g., with ADHD; White \& Shah, 2006). Therefore, shifting training might prove to be successful in promoting transfer effects and improving performance in cognitive tasks that are related to fluid intelligence (Kray \& Ferdinand, 2014). Still, there is a lack of research that examines the effectiveness of the training on other measures of daily functioning, such as PM. Overall, more research is needed to provide conclusive comments on the effectiveness of shifting and inhibition training.

\section{Aim of this study}

The aim of this study was to examine whether inhibition and shifting training can enhance the trained abilities and lead to near and far transfer. More specifically, our hypothesis was that inhibition training would lead to largest effect on the trained task, to large effects on other inhibition tasks (near transfer) and to smaller but significant effects on WM and event-based PM (far transfer). A similar hypothesis was made for shifting training: The largest effect was expected for the trained task, large effects for other shifting tasks (near transfer) and smaller effects for WM and time-based PM (far transfer). We did not expect differences between groups that received inhibition or shifting training on WM task.

\section{Method}

\section{Participants}

First year psychology students at University of Zagreb $(N=75)$ participated in the study for class credit, which ensured for maximum adherence. Data for at least one cognitive task was missing for four of them, which is why they were omitted from further analyses. In the remaining sample $(N=71,18$ males), the average age was 19.5 years $(S D=1.3, \min =18, \max =26)$. On average, they reported to spend 1.3 hours weekly playing games on their computer or mobile phone $(\min =0, \max =15)$. They did not report of any disabilities that would prevent them from participating in the training.

A separate group of students of psychology from University of Ljubljana $(n=36)$ formed a control group. Data with this group were gathered for different purposes within a study designed to validate a newly-developed test for measuring executive functions called CCRacer (Lah, 2020). We decided to present them here to provide additional support for our findings. In the control group, the average age was 20.5 years $(S D=3.1, \min =18, \max =31)$ and there were 5 males (14\%). On average, they reported to spend 1.6 hours weekly playing games on their computer or mobile phone $(\min =0, \max =35)$.

\section{Research design}

Participants from University of Zagreb were randomly assigned to two groups. Group $1\left(n_{1}=36\right)$ participated in inhibition training via the Simon Task training. Group 2 $\left(n_{2}=35\right)$ was trained in shifting abilities by training with the Task Switching Paradigm. The two groups trained for 
approximately 20 minutes a day, three times a week, for four weeks (12 sessions in total). Since both groups received a comparable amount of training, but with different cognitive tasks, each group can be considered an active control to the other group training a different cognitive function. The control group from University of Ljubljana did not receive any specific training with cognitive tasks and was considered a passive control group.

\section{Training tasks}

The Simon Task and Task Switching Paradigm(Alternating Runs Version) (PsyToolkit; Stoet, 2017) were used within the training. The instructions and stimuli were translated to Croatian language.

The Simon task (Stoet, 2017). In this task, stimuli which are either compatible or incompatible with the required response are presented to the participants; i.e. words "Left" and "Right" ("lijevo" and "desno" in Croatian language) are either presented on the left or the right side of the fixation point (see Figure 1a). In the compatible condition, the location and the meaning of the word match, e.g., the word "Left" is shown on the left side of the screen, and the participants need to respond by pressing the "A" key with their left hand. In the incompatible condition, the word location and meaning do not match, e.g., the word "Right" is shown on the left side of the screen, and participants need to press the "L" key with their right hand. Half of trials are the compatible condition trials and the other half are the incompatible condition trials. Within both the compatible and incompatible condition, half of the stimuli are presented on the left side of the screen and the other half are presented on the right side of the screen. Different conditions are presented in random order. Participants typically respond faster and more accurately if there is a match between stimulus and response features (word meaning and location). In our study, each training session consisted of 375 trials altogether.

The Task Switching Paradigm (Rogers \& Monsell, 1995). Participants are shown a $2 \times 2$ grid and a number-letter pair in one of the quadrants (see Figure 1b). When the pair is shown in one of the upper two quadrants, they need to respond according to the letter by pressing the "B" key for consonants or the "N" key for vowels. When the pair is shown in one of the lower quadrants, participants respond by pressing the " $\mathrm{B}$ " key for odd numbers and the " $N$ " key for even numbers. In the first block of trials ( 25 trials), only upper two quadrants are

\section{Figure 1}

Screenshot of (a) Simon task and (b) Task Switching Paradigm

(b)

(a)

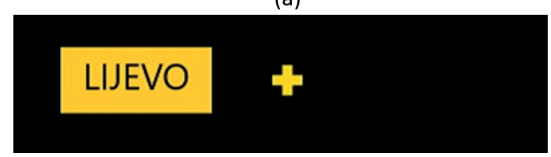

used and participants respond to letters only. In the second block ( 25 trials), they are asked to respond to numbers only. In the third and fourth block (300 trials altogether), they respond to both letters and numbers (the pairs are presented clockwise in successive quadrants, with two trials for letters, followed by two trials for numbers; a task switch occurs every two trials). In this task, the difficulty to shift between tasks is typically expressed as the slow down immediately following a task switch.

\section{Transfer tasks}

Both training tasks were used as criterion tasks for the trained ability (for task descriptions see Training tasks section). CCRacer Go/No-Go and PEBL Go/No-Go were used as near transfer tasks for inhibition training, while CCRacer Crossroads and PEBL Switcher were used as near transfer tasks for shifting training. Prospective memory task was used as a measure of far transfer.

The Simon task. In the pretest and posttest version, the task was composed of 150 trials that lasted about 7 min, with exercise trials excluded from the posttest version. Accuracy and RTs on compatible and incompatible trials with correct responses were recorded.

Task Switching Paradigm. The task was composed of four blocks (50 trials each). The test time was about $7 \mathrm{~min}$. Accuracy and RTs in each trial were recorded.

CCRacer Go/No-Go task. The go/no-go task measures the ability to inhibit dominant responses and deficits in attention and inhibition (Bezdjian et al., 2009). This is a gamified version of the go/no-go task and involves a simulation of car-driving during which a black or white smoke appears on a two-lane road ahead of the vehicle every $1000 \mathrm{~ms}$. The participant needs to avoid black smoke (change the lane) by pressing one of the arrow keys (the "go" condition) or drive through the white smoke (the "no go" condition). In the study, the incidence of white smoke ("no go") conditions was $20 \%$ in the first block of trials (33 trials out of 165) and $80 \%$ in the second block of trials (132 trials out of 165). The test took about $7 \mathrm{~min}$ to complete (the participants could take a short break during the first and the second block if needed). We recorded the accuracy and RTs of the responses. In this study, only data from the first block were analysed as this part is the one typically measuring inhibition ability.

PEBL Go/No-Go task. A square with four quadrants, each containing a blue star, was presented on the screen. After $1500 \mathrm{~ms}$, one of the squares disappeared and a letter appeared at its place for $500 \mathrm{~ms}$. The test had two parts composed of 20 letters "R" and 80 letters "P" presentations (trials were grouped in blocks of 5, with the 4:1 ratio of both types of stimuli). In the first part of the test, participants had to press the button as quickly as possible if the letter $\mathrm{P}$ was presented and had to withhold response if the letter $\mathrm{R}$ was presented. In the second part, they needed to respond to the letter $\mathrm{R}$ and not respond to the letter P. A short break could be taken between the two blocks. The test lasted about $6 \mathrm{~min}$. The accuracy and RTs of responses were recorded. In this study, only data from the first part of the test were analysed as this part is the one typically measuring inhibition ability. 
CCRacer Crossroads task. The test measures the ability to switch between different rules. The task involves a simulated car ride in which the participants turn left or right at a Y-intersection by pressing one of the arrow keys according to the solution of a task presented on the car display. A onedigit number was presented on the display $2000 \mathrm{~ms}$ prior to arriving at the intersection together with two types of decision rules. One of the rules was to decide whether the presented number is odd or even, and the second rule was to decide whether the number is smaller or larger compared to the one presented for the previous intersection. The first block contained 26 intersections with the odd-even rule. The second block contained 26 intersections with the largersmaller rule. The third block contained 52 intersections with alternate presentation of both rules (odd-even, larger-smaller, odd-even, larger-smaller, etc.). The test took about $7 \mathrm{~min}$ to complete (the participants could take a short break between different blocks if needed). The accuracy and RTs of the decisions were recorded.

PEBL Switcher task (Anderson et al., 2012). The test measures the ability to switch between rules. The screen shows 10 figures of different shapes and colours containing different letters. Participants must click on the figures sequentially and in accordance with the rule (the next figure must be the same shape, colour, or have the same letter as the current figure), and the rules change after each click. The test has three parts. In the first one, two rules alternate in a sequence, in the second, three rules alternate in a sequence, and in the third, three rules alternate in an inconsistent sequence. In each part of the test, the average time before clicking the next target in the set is measured. In total, the test lasted 6 minutes (participants could take a short break if needed between parts of the test).

Prospective memory (PM) task. A 10-min task was developed to measure two aspects of PM: event-based and time-based PM (Kvavilashvili \& Ellis, 1996). The PM task was an ongoing task embedded within the OSPAN task (Conway et al., 2005). The OSPAN task is a WM task which requires solving of arithmetic equations while memorizing the sequence of letters. A simple equation (summation or subtraction with three single digits) is shown, and participants have to click on a web-button "STOP", right below the equation, when they have computed the solution to the equation. Upon stopping, two numbers are displayed on the screen, one representing the correct and the other incorrect solution. When the solution is selected, a letter-to-be-remembered is displayed for $1 \mathrm{~s}$. The number of correctly solved equations and the number of correctly memorized letters are measured as an estimate of WM span. The test is adaptive. It starts with a sequence of 3 equations/letters, and then the number of to-be-remembered letters is increased by 1 in the next trial if the participant correctly recalls the entire sequence of letters, or decreased by 1 if the sequence of letters is unsuccessfully recalled. The result is the proportion of correctly solved equations and the maximum number of letters remembered (digit memory span). During operational memory span tasks, participants have two additional tasks. Whenever number "5" appears in the equation, they have to press the " 5 " key (eventbased PM task). The number of hits and misses of number "5" is recorded, and the proportion of hits is taken as a measure of event detection accuracy. Additionally, participants have to click the web-button "3 min have elapsed", shown on the screen, 3, 6, and 9 min after the start of the experiment (time-based PM task), and they can check how much time has elapsed by pressing a web-button "Check time" on the screen. The timing of clicking the web-button "Check time" and " 3 minutes have elapsed" is recorded. The response is considered accurate if the " 3 minutes have elapsed" button is pressed within the time period of $180 \mathrm{~s} \pm 2.5 \mathrm{~s}$ from the beginning of the interval. Maximum number of correct time responses is 3 .

\section{Procedure}

The pre- and posttest were conducted using Psytoolkit (Stoet, 2010, 2017), PEBL (Mueller \& Piper, 2014) and CCRacer (Prosenik, 2019) software. PsyToolkit tasks were run online, while computerized tasks from the PEBL and CCRacer were run offline. PEBL is a free-to-use battery of cognitive tests (Mueller \& Piper, 2014). CCRacer is a serious computer game for measuring different executive functions (Prosenik, 2019). In the pretest and posttest, participants responded by pressing different keys on the computer keyboard or by clicking the mouse button. All cognitive tests included brief instructions for participants about the stimuli, the task, and ways of responding. Each test began with a short exercise in which the participants got acquainted with the task.

To avoid complications and loss of data, which could have occurred due to different software in which tasks were presented, and to enable smoother measurement procedure, tasks from the same environment were combined in a sequence and presented in the same order to all the participants in the inhibition- and shifting-training group. The order of the tasks was as follows: (1) PM task, (2) CCRacer Go/No-Go, (3) CCRacer Crossroads, (4) PEBL Go/No-Go, (5) PEBL Switcher, (6) PsyToolkit Simon Task, (7) PsyToolkit Task Switching. The control group was tested with tasks 3, 2, 4 and 7 in the listed order, while other tasks were performed between tasks 2 and 4, and tasks 4 and 7 .

The pretest and posttest were carried out individually at university laboratories, and took $60 \mathrm{~min}$ and $50 \mathrm{~min}$, respectively (with brief pauses between tests). Trainings were performed individually at participants' homes (approx. $20 \mathrm{~min}$ per session). Participants ran the assigned training task online at their own convenience, with the rate of three sessions per week (limitation of one session per day). Their performance was monitored and data recorded.

All participants have signed the informed consent form. The study was approved by the Ethical Committees of the Faculty of Humanities and Social Sciences at the University of Zagreb and the Faculty of Arts at the University of Ljubljana.

\section{Data analysis}

RTs to correct trials were analysed (except in the "no go" condition of various Go/No-Go tasks where RT represents the time elapsed until responding incorrectly). Since 


\section{Figure 2}

The difference between reaction times to the incompatible and compatible conditions of the Simon task in different sessions of the inhibition training

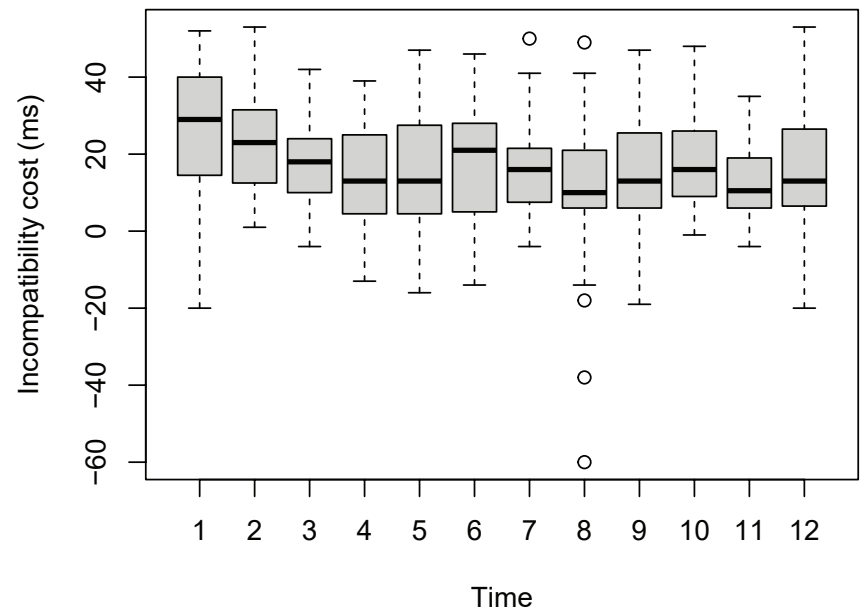

the frequency distributions of individual's RTs within a certain experimental condition typically showed a positive asymmetry, we calculated the median RT for each participant in each condition.

In the Simon task, the incompatibility cost was calculated as the difference between the median RTs to the incompatible and compatible conditions; the smaller the difference, the better the inhibition ability. In the Task Switching Paradigm and CCRacer Crossroads task, switching cost was calculated as the difference between the median RT in the mixed conditions with two interchanging rules and the median RT in two one-rule conditions (i.e., the median RT in the letters only and the numbers only conditions in the Task Switching Paradigm, and the median RT in the odd-even only and the smaller-larger only conditions in the CCRacer Crossroads task). Therefore, switching cost indicated how RTs changed when participants needed to switch between different rules in comparison to the situation when only one rule was present. Since the PEBL Switcher task does not include a single-rule condition, two different switching costs were calculated, one showing the difference between the median RTs in the tworule condition and the condition with three rules intermixed in a consistent manner, and the other showing the difference between the median RTs in the condition with three rules changing inconsistently and the condition with three rules changing consistently.

Statistical analyses were performed with $R$ (R Core Team, 2019). Due to the non-normal distributions of data, robust descriptive statistics (median and MAD, i.e., median absolute deviation from the median adjusted by a factor of 1.48 for asymptotically normal consistency) were calculated for each training group separately. Gains in the observed measures from pretest to posttest measurements were compared to 0 with Wilcoxon one-sample signed-rank test. One-tailed testing was used, as we expected positive gains (increase) in accuracy and negative gains (decrease) in RTs due to the effect of cognitive training or practice. Gains in the training group were next compared to gains in the active control

\section{Figure 3}

The difference between reaction times to the task-switch and same-task conditions of the Task Switching Paradigm in different sessions of the shifting training

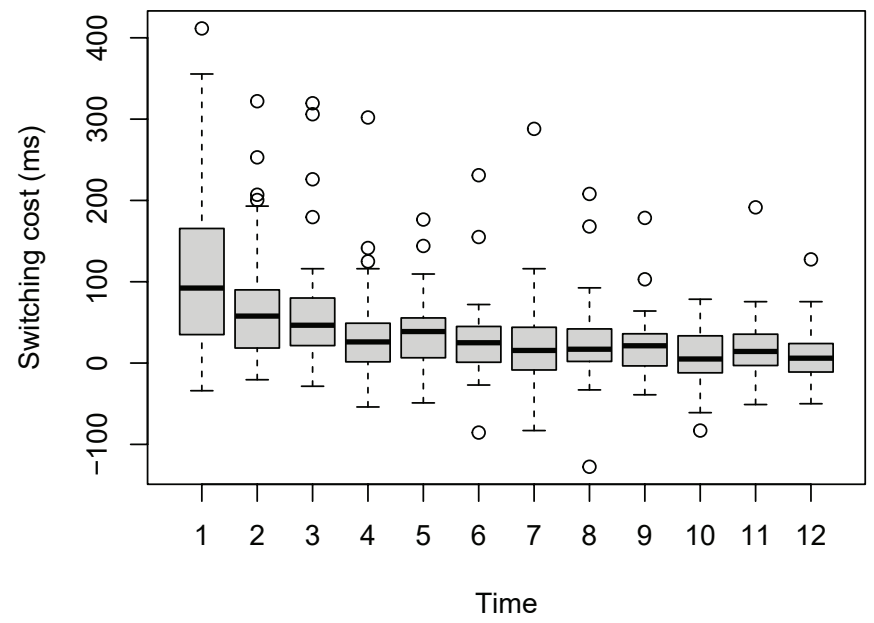

group and gains in the passive control group by using the two separate exact Wilcoxon-Mann-Whitney rank-sum tests. A one-tailed test was used in cases where larger gains could be expected in the training group compared to the other two groups (inhibition measures were expected to change more in the inhibition training, and task switching measures were expected to change more in the shifting training group) and a two-tailed test was used in case of WM and PM where no specific differences in gains were expected between the groups compared. We decided to reject the null hypotheses at the $0.1 \%$ alpha error rate due to multiple statistical tests carried out. Vargha and Delaney's (2000) $A$ was used as a measure of effect size for the difference between two groups. This measure reports the probability that a value from one group will be greater than a value from the other group.

\section{Results}

Both the inhibition training and the shifting training led to an improvement of the trained ability. In the inhibition training group, incompatibility costs in the Simon task decreased with the training session (Figure 2). Similarly, switching costs in the Task Switching Paradigm decreased with the training session in the shifting training group (Figure 3). In general, the decrease in incompatibility and switching costs was more pronounced in the first four sessions than in the later ones. With the training, both costs asymptotically approached the lower limit (about $10 \mathrm{~ms}$ ).

We analysed the accuracy of the responses obtained in different inhibition tasks and their RTs. Table 1 shows the gains in performance measures (accuracy and reaction times) from pretest to posttest in the three groups (for descriptive statistics of these performance measures see Table A1 in the Appendix). In terms of accuracy, no systematic improvements from pretest to posttest were found in any of the inhibition tasks and in any of the groups (Table 1). The gain in accuracy of the inhibition training group in the 
"no go" condition of the CCRacer Go/No-Go task was almost statistically significantly different from $0(p=.009)$ and was slightly (but not statistically significantly) greater than in the control group.

Regarding the reaction times to the Simon task, both the training group (i.e. the inhibition group) and the active control group (i.e. the shifting group) showed statistically significant improvements from pretest to posttest (Table 1), but the improvements were (statistically significantly, with $p<.001$ ) greater in the inhibition training group, both in the compatible and incompatible conditions of the task (consequently, the incompatibility costs decreased to a similar extent in both groups). According to the categories of Vargha and Delaney's measure of effect size described in Mangiafico (2016), the differences in gains between the two groups were large (the values of $A$ were larger than .76 and therefore much larger than .50 showing no effect). While improvements in RTs in the shifting group indicate the effect of practice (during the pretest the participants familiarised themselves with the task and developed some strategies), inhibition training improved RTs in both conditions of the Simon task beyond what could be expected based on the practice effect alone.

In the two other cognitive tasks for measuring inhibition (PEBL Go/No-Go and CCRacer Go/No-Go) no significant improvements in RTs were observed in either group. The three groups did not differ in the RT improvements from pretest to posttest.
Table 2 shows the comparison of gains in accuracy and RTs under different conditions of the switching tasks (descriptive statistics for the pre- and posttest performance measures in the switching tasks in all three groups are available in the Appendix, Table A2). The changes in the accuracy of the responses in Task Switching Paradigm were small, mainly because the accuracies were already relatively high at the pretest (see Table A1). In the CCRacer Crossroads the accuracy slightly increased from pretest to posttest, but the increase was observed in all three groups and did not differ statistically significantly between groups. All groups also showed faster responses in Task Switching Paradigm in the posttest compared to the pretest measurements. However, these improvements were much larger in the shifting training group than in the inhibition and control groups. The switching cost in this task also decreased more in the shifting group than in the inhibition and control group. The effect sizes were large (the values of Vargha and Delaney's measure of effect size were greater than 0.85). These results showed that training with the PsyToolkit Task Switching Paradigm was effective beyond the improvements that could be attributed to the practice effect. Large improvements in RTs from pretest to posttest were also observed in some conditions of other switching tasks, e.g. in the single rule (odd-even number) condition and the switching-between rules (mixed) condition in the CCRacer Crossroads task, where the gains in the shifting training group were slightly larger than in the other

\section{Table 1}

Median gains (and MADs in the parentheses) in different parameters of the inhibition tasks in the three groups

\begin{tabular}{|c|c|c|c|c|c|c|c|c|c|}
\hline \multirow[b]{2}{*}{ Observed variables } & \multirow{2}{*}{$\begin{array}{l}\text { Inhibition } \\
\text { training } \\
\text { group } \\
(n=36)\end{array}$} & \multirow{2}{*}{$\begin{array}{l}\text { Shifting } \\
\text { training } \\
\text { group } \\
(n=35)\end{array}$} & \multirow{2}{*}{$\begin{array}{l}\text { Control } \\
\text { group } \\
(n=36)\end{array}$} & \multicolumn{3}{|c|}{$\begin{array}{l}\text { Inhibition vs. shifting } \\
\text { training group }\end{array}$} & \multicolumn{3}{|c|}{$\begin{array}{l}\text { Inhibition training vs. } \\
\text { control group }\end{array}$} \\
\hline & & & & $Z$ & $p$ & $A$ & $Z$ & $p$ & $A$ \\
\hline \multicolumn{10}{|l|}{ Accuracy } \\
\hline Simon task: Compatible & $-.04(.06)$ & $-.01(.02)$ & -- & -1.84 & .968 & .37 & -- & -- & -- \\
\hline Simon task: Incompatible & $.03(.07)$ & $.01(.07)$ & -- & 0.04 & .485 & .50 & -- & -- & -- \\
\hline PEBL Go/No-Go: No go & $.00(.10)$ & $.00(.20)$ & $.00(.00)$ & 0.01 & .499 & .50 & 0.80 & .214 & .54 \\
\hline PEBL Go/No-Go: Go & $.00(.00)$ & $.00(.00)$ & $.00(.00)$ & -0.58 & .683 & .48 & -1.64 & .959 & .42 \\
\hline CCRacer Go/No-Go: No go & $.12(.20)$ & $.06(.18)$ & $.00(.13)$ & 1.31 & .096 & .59 & 1.99 & .023 & .64 \\
\hline CCRacer Go/No-Go: Go & $.00(.00)$ & $.00(.00)$ & $.00(.00)$ & -0.55 & .709 & .47 & -0.39 & .654 & .48 \\
\hline \multicolumn{10}{|l|}{ Reaction times } \\
\hline Simon task: Compatible & $-65(36)$ & $-27(28)$ & -- & 3.83 & $<.001$ & .76 & -- & -- & -- \\
\hline Simon task: Incompatible & $-89(26)$ & $-46(43)$ & -- & 4.48 & $<.001$ & .81 & -- & -- & -- \\
\hline Simon task: Incompatibility cost & $-32(29)$ & $-27(22)$ & -- & 0.95 & .172 & .57 & -- & -- & -- \\
\hline PEBL Go/No-Go: No go ${ }^{\mathrm{a}}$ & $3(46)$ & $-4(38)$ & $2(41)$ & -0.39 & .653 & .33 & -0.15 & .559 & .39 \\
\hline PEBL Go/No-Go: Go & $-5(37)$ & $-1(31)$ & $-1(33)$ & 0.19 & .426 & .51 & 1.61 & .054 & .61 \\
\hline CCRacer Go/No-Go: No go & $8(32)$ & $14(50)$ & $5(38)$ & 0.10 & .462 & .51 & -1.00 & .840 & .45 \\
\hline CCRacer Go/No-Go: Go & $9(42)$ & $-6(39)$ & $10(39)$ & -1.25 & .894 & .41 & 0.57 & .285 & .54 \\
\hline
\end{tabular}

Note. Statistically significant gains $(p<.001)$ are printed in bold. $Z$ - result of the Wilcoxon rank-sum test. $A$ - Vargha and Delaney's measure of effect size. ${ }^{\text {IIn }}$ this tasks, RT from 31 participants were analysed for the pretest and the posttest (other participants had a 100-percent accuracy in the No go conditions); 28 participants reacted at least once in this condition both in the pretest and the posttest measurements and their data were included in the analysis of gain. The number of the data included in the analyses was (coincidentally) the same in both groups. 
Table 2

Median gains (and MADs in the parentheses) in different parameters of the switching tasks in the three groups

\begin{tabular}{|c|c|c|c|c|c|c|c|c|c|}
\hline \multirow[b]{2}{*}{ Observed variables } & \multirow{2}{*}{$\begin{array}{c}\text { Inhibition } \\
\text { training group } \\
(n=36)\end{array}$} & \multirow{2}{*}{$\begin{array}{l}\text { Shifting } \\
\text { training } \\
\text { group } \\
(n=35)\end{array}$} & \multirow{2}{*}{$\begin{array}{l}\text { Control } \\
\text { group } \\
(n=36) \\
\end{array}$} & \multicolumn{3}{|c|}{$\begin{array}{l}\text { Shifting vs. inhibition } \\
\text { training group }\end{array}$} & \multicolumn{3}{|c|}{$\begin{array}{l}\text { Shifting training vs. } \\
\text { control group }\end{array}$} \\
\hline & & & & $Z$ & $p$ & $A$ & $Z$ & $p$ & $A$ \\
\hline \multicolumn{10}{|l|}{ Accuracy } \\
\hline \multicolumn{10}{|l|}{ Task Switching Paradigm } \\
\hline Letters only & $.00(.03)$ & $.00(.06)$ & $.02(.04)$ & -0.41 & .660 & .53 & -1.78 & .963 & .38 \\
\hline Numbers only & $-.02(.06)$ & $-.02(.06)$ & $-.03(.04)$ & 0.11 & .458 & .49 & 0.42 & .340 & .53 \\
\hline Mixed, switch & $-.02(.04)$ & $.00(.03)$ & $.00(.07)$ & 2.86 & .002 & .31 & 0.45 & .328 & .53 \\
\hline Mixed, no switch & $-.02(.03)$ & $-.02(.06)$ & $.00(.04)$ & -0.91 & .819 & .56 & -1.15 & .875 & .42 \\
\hline \multicolumn{10}{|l|}{ CCRacer Crossroads } \\
\hline Odd-even only & $.00(.00)$ & $.00(.06)$ & $.04(.06)$ & 1.48 & .070 & .41 & -1.18 & .881 & .42 \\
\hline Smaller-larger only & $.04(.05)$ & $.04(.05)$ & $.06(.08)$ & -0.01 & .504 & .50 & -1.63 & .949 & .38 \\
\hline Mixed & $.01(.04)$ & $.02(.03)$ & $.04(.06)$ & 1.10 & .137 & .43 & -1.98 & .976 & .36 \\
\hline \multicolumn{10}{|l|}{ Reaction times } \\
\hline \multicolumn{10}{|l|}{ Task Switching Paradigm } \\
\hline Letters only & $-62(64)$ & $\mathbf{- 2 1 7}(67)$ & $-54(66)$ & 6.57 & $<.001$ & .95 & 6.63 & $<.001$ & .96 \\
\hline Numbers only & $-62(42)$ & $-174(62)$ & $-22(64)$ & 6.21 & $<.001$ & .93 & 6.54 & $<.001$ & .95 \\
\hline Mixed, switch & $-263(153)$ & $-661(239)$ & $-133(202)$ & 6.15 & $<.001$ & .93 & 6.25 & $<.001$ & .93 \\
\hline Mixed, no switch & $-102(73)$ & $-223(123)$ & $-47(99)$ & 5.37 & $<.001$ & .87 & 5.60 & $<.001$ & .89 \\
\hline Switching cost & $-\mathbf{1 8 4}(126)$ & $-488(217)$ & $-\mathbf{1 1 7}(162)$ & 5.01 & $<.001$ & .85 & 5.42 & $<.001$ & .87 \\
\hline \multicolumn{10}{|l|}{ CCRacer Crossroads } \\
\hline Odd-even only & $-\mathbf{1 7 0}(150)$ & $-252(141)$ & $-\mathbf{1 8 1}(105)$ & 2.62 & .004 & .68 & 2.16 & .015 & .65 \\
\hline Smaller-larger only & $-146(133)$ & $-\mathbf{1 7 7}(120)$ & $-196(133)$ & 0.28 & .391 & .52 & -0.49 & .689 & .48 \\
\hline Mixed & $-121(74)$ & $-172(178)$ & $-\mathbf{1 1 0}(102)$ & 1.68 & .047 & .62 & 1.90 & .029 & .63 \\
\hline Switching cost & $31(105)$ & $10(126)$ & $73(99)$ & 0.35 & .365 & .52 & 1.34 & .091 & .60 \\
\hline \multicolumn{10}{|l|}{ PEBL Switcher } \\
\hline Two rules & $-\mathbf{2 4 0}(185)$ & $-262(159)$ & -- & 0.63 & .267 & .54 & -- & -- & -- \\
\hline Three rules - consistent & $-216(145)$ & $-\mathbf{3 3 5}(199)$ & -- & 1.57 & .059 & .61 & -- & -- & -- \\
\hline Three rules - inconsistent & $-64(209)$ & $-148(230)$ & -- & 1.78 & .038 & .62 & -- & -- & -- \\
\hline Switching cost & $20(249)$ & $-49(230)$ & -- & 0.99 & .162 & .57 & -- & -- & -- \\
\hline Switching cost & $162(197)$ & $109(268)$ & -- & 0.53 & .299 & .54 & -- & -- & -- \\
\hline
\end{tabular}

Note. Statistically significant gains $(p<.001)$ are printed in bold. $Z$ - result of the Wilcoxon rank-sum test. $A$ - Vargha and Delaney's measure of effect size.

Table 3

Median gains (and MADs in the parentheses) in the working and prospective memory tasks in the two training groups

\begin{tabular}{lrrrrr}
\hline & $\begin{array}{c}\text { Inhibition } \\
\text { training } \\
\text { Observed variables }\end{array}$ & \begin{tabular}{c} 
Shifting \\
training \\
group \\
\cline { 3 - 6 }
\end{tabular} & $\begin{array}{c}\text { group } \\
(n=36)\end{array}$ & \multicolumn{2}{c}{ Wilcoxon rank-sum test } \\
\hline WM: Equation solving accuracy & $.00(.03)$ & $.00(.03)$ & -1.17 & .246 & .42 \\
WM: Maximum number of letters remembered & $0(1.5)$ & $0(1.5)$ & 0.68 & .502 & .55 \\
Event-based PM: Event detection accuracy & $.11(.16)$ & $.07(.14)$ & 0.81 & .425 \\
Time-based PM: Number of time checks & $1(5.2)$ & $2(4.5)$ & -0.42 & .678 & .47 \\
Time-based PM: Number of correct time responses & $0(1.5)$ & $0(1.5)$ & -0.40 & .686 & .47 \\
\hline
\end{tabular}

Note. Statistically significant gains $(p<.001)$ are printed in bold. $A$-Vargha and Delaney's measure of effect size and shows the probability of an observation in the Shifting training group being larger than an observation in the Inhibition training group. 


\section{Figure 4}

Effect sizes (Vargha and Delaney's A) on selected performance measures of inhibition and shifting.

(1) Simon task: Incompatible (RT)

(2) Task Switching Paradigm: Mixed, switch (RT)

(3) Task Switching Paradigm: Switching cost (RT)

(4) PEBL Go/No-Go: No go (Accuracy)

(5) CCRacer Go/No-Go: No go (Accuracy)

(6) CCRacer Crossroads: Mixed (RT)

(7) CCRacer Crossroads: Switching cost (RT)

(8) PEBL Switcher: Two rules (RT)

(9) PEBL Switcher: Three rules - consistent (RT)

(10) PEBL Switcher: Three rules - inconsistent (RT)

(11) PEBL Switcher: Switching cost (9)-(8)

(12) PEBL Switcher: Switching cost (10)-(9)

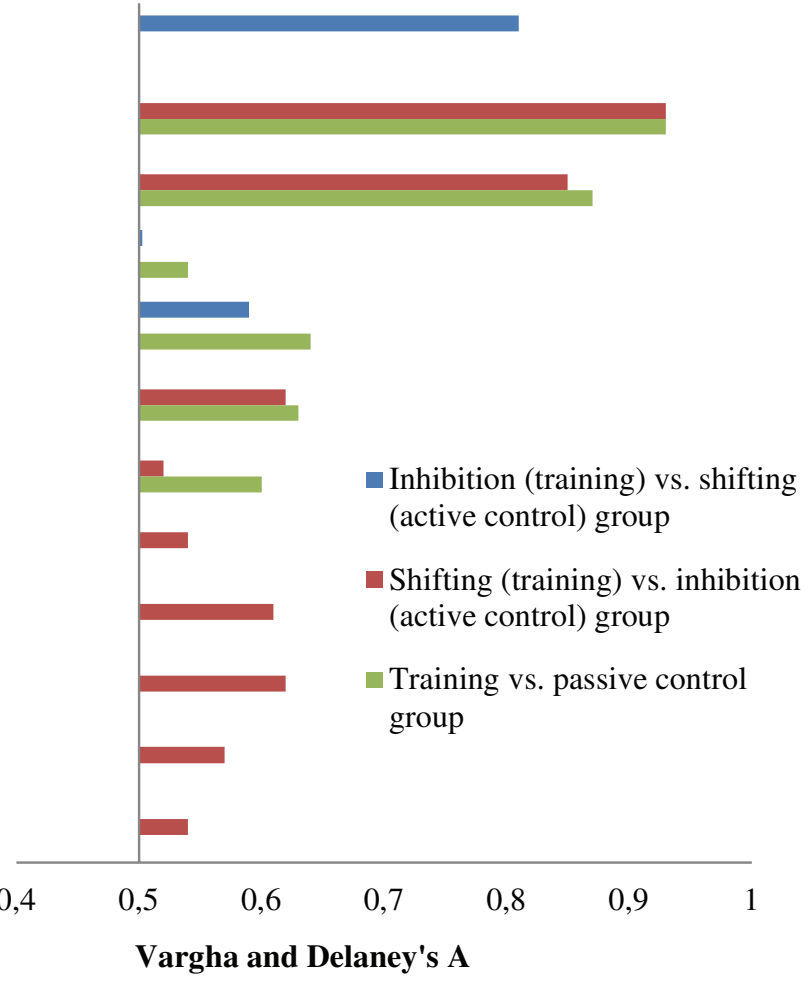

Notes. Performance measures were compared in the training and active control group (blue bars) and in the training and passive control group (red bars). Measures 1-3 are measures of performance on the trained tasks, measures 4-12 are measures of performance on neartransfer tasks. $\mathrm{RT}=$ reaction times.

two groups, but this advantage of the shifting training group did not reach statistical significance. The gains in switching costs were not informative because RTs generally decreased both in single-rule and mixed-rule conditions. The decrease in RTs was greater in single-rule conditions than in mixedrule conditions, leading to an increase in switching costs from pretest to posttest.

The prospective memory task taps cognitive functions that are not directly related to the trained abilities (event- and time-based PM, WM). Performance gains in this task are described in Table 3 (descriptive statistics are listed in Table A3 in the Appendix). The accuracy in solving equations did not improve from pretest to posttest (it was already high in the pretest), nor did the maximum number of letters remembered, the number of time checks, or the number of correct responses in the time-based PM task. Event detection accuracy, i.e. the proportion of cues (numbers " 5 ") detected in the event-based PM task, improved in both groups to a similar extent. In the inhibition training group the improvement reached statistical significance $(p<.001)$.

Figure 4 shows a summary of comparisons of gains in the group that trained a particular cognitive function and the other two groups. Only the effects on selected measures that most directly indicate improvements in inhibition and switching are shown. Vargha and Delaney's A values greater than 0.5 indicate a larger gain in the training group compared to the control group. Remarkable effects of training on performance measures were observed in the trained tasks (see measures 1-3 in Figure 4), while the effects on the near-transfer tasks (measures 4-12) were smaller.

\section{Discussion}

Due to the ceiling effect, most of the accuracy measures did not show any major changes from the pretest to the posttest. However, for most RT measures the results showed a relatively strong effect of the pretest on the posttest measurements. During the pretest, the participants familiarised themselves with different tasks, and one month later, when the posttest was performed, their reactions were much faster than during the initial testing. This effect of practice was pronounced in all three groups.

In both the inhibition training group and the shifting training group, clear and statistically significant gains in RTs were observed in different conditions of the trained task, exceeding those that could only be attributed to the practice effect. In Task Switching Paradigm, the excessive gain was 
found in the shifting training group compared to both the active and passive control group. Unfortunately, the passive control group was not subjected to the Simon task, so we cannot be sure to what extent the gains in RTs found in the inhibition training group in this task reflect the practice vs. far transfer effects. The gain in this group could be either a result of the practice effect, a result of the far transfer effect of inhibition training, or a result of both. Future studies should investigate this open question.

In our study, all three groups had similar gains in RTs in near and far transfer tasks from pretest to posttest, indicating the effect of practice and only a very small, statistically insignificant and therefore unconvincing additional effect of training. In other words, the effect of cognitive training significantly exceeded the practice effect only in the trained tasks. These results are not consistent with studies that show a training effect on other tasks and cognitive abilities (e.g. Karbach \& Verhaeghen, 2014; Kray \& Ferdinand, 2014). Although the results support studies that claim that transfer effects are limited to trained tasks only (e.g. Sala \& Gobet, 2019), the absence of transfer could be the result of several factors (see Katz et al., 2016), which will be discussed later in the text.

We expected that the inhibition training with the Simon task would also lead to an improvement of the RTs in the go/ no-go tasks. However, no excessive gain in the go/no-go tasks was observed in the inhibition training group compared to the shifting training group. Although the absence of near-transfer effects may be surprising, limited transfer of inhibition training was also found in other studies (Dowsett \& Livesey, 2000; Thorell et al., 2009). In addition, low correlations were found between different inhibition measures, for example, between the measures of Stroop task and stop-signal RT (Khng \& Lee, 2014).

Our results could indicate that the RTs for the Simon task and go/no-go tasks are influenced by different underlying processes. The Simon task contains two overlapping stimulus-response dimensions - semantics and spatial location dimension (e.g., in response to the word "right", participants must press the button on the right regardless of the spatial location of the stimulus). The increase in RTs occurs when the prepotent spatial location dimension is incompatible with the semantic dimension and the spatial location response interferes with the semantic dimension response. The participant must respond to each trial, but the choice of response (left or right hand) must be related to the result of processing the two dimensions together. In this case, inhibition refers to the inhibition of one of the two parallel cognitive processes and the resolution of the conflict between them (e.g. Pellicano et al., 2009). In contrast, the go/no-go task requires participants to respond quickly to a visual stimulus in the "go" trials and to withhold the response in the "no go" trials. Participants must inhibit the predominant "go" response, and inhibition is possible if the processing of the "no go" signal is fast and the prepotent response is stopped in time. Inhibition therefore refers to the cancellation of the motor response (Simmonds et al., 2008). It appears that the two types of cognitive tasks tap into different aspects of inhibition (inhibition of a competing decision vs. inhibition of motor response; Bernal \& Altman, 2009). This assertion is also supported by the general comparison of RTs in the Simon task and two go/no-go tasks. The RTs of the Simon task were slightly longer than those of the PEBL and CCRacer Go/No-Go tasks (see Table A1 in the Appendix), indicating that underlying processes in the two task types may be different. According to our results, which showed no convincing transfer of the inhibition training effect from the Simon task to the two go/no-go tasks, training the first aspect of inhibition, i.e. inhibition of the interference of irrelevant stimulus dimension processing, does not lead to an improvement of the second aspect of inhibition, i.e. motor response inhibition.

Similarly, the use of different stimuli or switching rules in our tasks seems to limit the transfer effects of the shifting training. For example, in the CCRacer Crossroads task, the group with the shifting training showed larger (though not statistically significantly larger) improvements in RTs in the odd-even condition and the mixed rule condition (consisting of both the odd-even rule and the smaller-larger rule) than the other two groups, while no such excessive improvements were observed in the CCRacer Crossroads condition containing only the smaller-larger rule. The excessive improvements in the first two conditions could perhaps be attributed to the specifics of the shifting training with the PsyToolkit Task Switching Paradigm. Namely, in one part of each training session, the participants had to decide whether the number shown was odd or even, which might have led to a greater gain in the CCRacer odd-even single rule (and also in the mixed rule condition containing the same rule). The characteristics of the CCRacer Crossroads single rule condition (smallerlarger) overlapped less with the characteristics of the trained Task Switching Paradigm, which did not lead to any particular excessive gains. Also in the PEBL Switcher, the improvements in switching between different rules were slightly greater for the shifting training group than for the active control group, but the difference did not reach statistical significance. To increase statistical power, future studies should include larger samples and a larger number of trials within cognitive tasks to derive more stable estimates of RTs under different conditions. Cognitive tasks with higher sensitivity (which prevent the ceiling effect in accuracy) should be performed to draw firm conclusions about the near transfer of the effects of inhibition or shifting training.

Since we have not found convincing near-transfer effects, the lack of far transfer (transfer to performance in eventbased PM, time-based PM and WM, i.e. OSPAN, tasks) is not surprising. The only measure where improvements were easily noticed was the accuracy of event detection, but the gain only reached statistical significance in the inhibition training group. This is consistent with many studies that confirm an important role of inhibition in focal event-based tasks (e.g. Kliegel et al., 2003). In these tasks, people are engaged in the central task (in our case OSPAN) in which the PM cue is embedded; therefore, they do not need to monitor the environment for PM cues. When the PM cue appears (in our case number 5 somewhere in the equation or its solution), they must inhibit their reaction to the central task (equation solving) in order to perform the PM task (Kliegel et al., 2003; Zuber et al., 2016). 
Both WM and PM are complex cognitive functions supported by many other cognitive functions, such as selective attention (Gazzaley \& Nobre, 2012) and retrospective memory (Burgess \& Shallice, 1997). Therefore, enhancing a single ability may not be sufficient when complex cognitive processes are involved. More complex interventions, such as multimodal training that combines inhibition and shifting in a single training, would probably have an advantage over the trainings conducted in this study. Future studies should also use a prospective memory task where the detection accuracy in the pretest would be very low, leaving much room for possible improvements through cognitive training.

Our study had several limitations. First, the results from WM are probably biased towards lower performance due to the additional PM task, so these should be considered with caution. Second, the training was presented online, at the participants' own pace, so the training conditions could not be controlled. Procedural differences could have been caused by different environmental distractors or the type of computers used. Future studies should apply a stricter control over the training procedure. Third, the participants in this study were students with highly developed cognitive abilities. This may have caused the celling effect, which hinders the further development of cognitive skills. EF have their peak during the age of 20, which raises the question of the usefulness of EF training at this age (e.g. Reynolds \& MacNeill Horton, 2008). Therefore, enhancing some other, more complex cognitive functions may be more effective in emerging adults. Fourth, it is difficult to motivate participants to do their best throughout the study. Pretest and posttest measurements lasted about one hour, and 12 training sessions each lasted 20 minutes. Lack of motivation may have had a negative impact on our results by reducing the improvements of RTs in the training group. This group performed the same task 14 times, compared to the control group that performed the test task for the second time in the posttest. Future research should include multiple versions of the trained task with more interesting interfaces, which could lead to a higher level of motivation during training. Fifth, the training was not adaptive. Previous studies have shown positive effects of adaptive training on maximum workload which promotes brain plasticity and leads to transfer (Edwards et al., 2018). Finally, we have not measured the durability of the effects (there was no follow-up). Some authors find in follow-up studies the so-called sleeper effect (Van der Molen et al., 2010), i.e. better performance some time after the end of training. Measuring the effects a few months after the end of training would provide additional information on the durability of the effects of training.

Although this study has some limitations, it is one of the rare studies that directly compared the effectiveness of inhibition and shifting training on trained and untrained abilities in emerging adults. The results confirmed significant improvements in performance in the trained task, but limited near and far transfer. More challenging training with motivational elements, addressing several different modalities, may help overcome the transfer barrier that is often encountered in cognitive training studies. Future studies are needed to clarify the role of basic EF in other complex cognitive abilities and to provide theoretical and practical implications in this area of research.

\section{Acknowledgment}

The authors acknowledge the financial support from the Slovenian Research Agency (research core funding No. P50110). We would like to thank Amadeja Lah for collecting part of the data.

\section{References}

Anderson, K., Deane, K., Lindley, D., Loucks, B., \& Veach, E. (2012). The effects of time of day and practice on cognitive abilities: The PEBL Tower of London, Trail-making, and Switcher tasks. Pebl Technical Report Series.

Au, J., Sheehan, E., Tsai, N., Duncan, G. J., Buschkuehl, M., \& Jaeggi, S. M. (2015). Improving fluid intelligence with training on working memory: A meta-analysis. Psychonomic Bulletin \& Review, 22(2), 366-377.

Baddeley, A. (2007). Oxford psychology series: Vol. 45. Working memory, thought, and action. Oxford University Press.

Baddeley, A., \& Hitch, G. J. (1974). Working memory. In G. A. Bower (Ed.), Recent advances in learning and motivation (pp. 47-90). Academic Press.

Barnett, S. M., \& Ceci, S. J. (2002). When and where do we apply what we learn? A taxonomy for far transfer. Psychological Bulletin, 128(4), 612-637.

Berkman, E. T., Kahn, L. E., \& Merchant, J. S. (2014). Training-induced changes in inhibitory control network activity. Journal of Neuroscience, 34(1), 149-157.

Bernal, B., \& Altman, N. (2009). Neural networks of motor and cognitive inhibition are dissociated between brain hemispheres: An fMRI study. International Journal of Neuroscience, 119(10), 1848-1880.

Bezdjian, S., Baker, L. A., Lozano, D. I., \& Raine, A. (2009). Assessing inattention and impulsivity in children during the Go/NoGo task. British Journal of Developmental Psychology, 27(2), 365-383.

Burgess, P. W., \& Shallice, T. (1997). The relationship between prospective and retrospective memory: Neuropsychological evidence. In M. A. Conway (Ed.), Studies in cognition. Cognitive models of memory (pp. 247-272). The MIT Press.

Chan, R. C. K., Shum, D., Toulopoulou, T., \& Chen, E. Y. H. (2008). Assessment of executive functions: Review of instruments and identification of critical issues. Archives of Clinical Neuropsychology, 23(2), 201-216.

Conway, A. R., Kane, M. J., Bunting, M. F., Hambrick, D. Z., Wilhelm, O., \& Engle, R. W. (2005). Working memory span tasks: A methodological review and user's guide. Psychonomic Bulletin \& Review, 12(5), 769-786. https:// link.springer.com/content/pdf/10.3758/BF03196772.pdf

Cowan, N. (2005). Essays in cognitive psychology. Working memory capacity. Psychology Press.

Dahlin, E., Nyberg, L., Bäckman, L., \& Neely, A. S. (2008). Plasticity of executive functioning in young and older adults: Immediate training gains, transfer, and long-term maintenance. Psychology and Aging, 23(4), 720-730. 
De Baene, W., Kühn, S., \& Brass, M. (2012). Challenging a decade of brain research on task switching: Brain activation in the task-switching paradigm reflects adaptation rather than reconfiguration of task sets. Human Brain Mapping, 33(3), 639-651.

De Simoni, C., \& von Bastian, C. C. (2018). Working memory updating and binding training: Bayesian evidence supporting the absence of transfer. Journal of Experimental Psychology: General, 147(6), 829-858.

Diamond, A. (2013). Executive functions. Annual Review of Psychology, 64, 135-168.

Dowsett, S. M., \& Livesey, D. J. (2000). The development of inhibitory control in preschool children: Effects of “executive skills" training. DevelopmentalPsychobiology, 36(2), 161-174.

Edwards, J. D., Fausto, B. A., Tetlow, A. M., Corona, R. T., \& Valdés, E. G. (2018). Systematic review and meta-analyses of useful field of view cognitive training. Neuroscience and Biobehavioral Reviews, 84, 72-91.

Ellis, J., \& Kvavilashvili, L. (2000). Prospective memory in 2000: Past, present, and future directions. Applied Cognitive Psychology, 14(7), S1-S9.

Friedman, N. P., \& Miyake, A. (2017). Unity and diversity of executive functions: Individual differences as a window on cognitive structure. Cortex, 86, 186-204.

Friedman, N. P., Miyake, A., Corley, R. P., Young, S. E., DeFries, J. C., \& Hewitt, J. K. (2006). Not all executive functions are related to intelligence. Psychological Science, 17(2), 172-179.

Gaál, Z. A., \& Czigler, I. (2018). Task-switching training and transfer: Age-related effects on late ERP components. Journal of Psychophysiology, 32, 106-130.

Gazzaley, A., \& Nobre, A. C. (2012). Top-down modulation: Bridging selective attention and working memory. Trends in Cognitive Sciences, 16(2), 129-135.

Houben, K. (2011). Overcoming the urge to splurge: Influencing eating behavior by manipulating inhibitory control. Journal of Behavior Therapy and Experimental Psychiatry, 42(3), 384-388.

Houben, K., Nederkoorn, C., Wiers, R. W., \& Jansen, A. (2011). Resisting temptation: Decreasing alcohol-related affect and drinking behavior by training response inhibition. Drug and Alcohol Dependence, 116(1-3), 132-136.

Karbach, J., \& Kray, J. (2009). How useful is executive control training? Age differences in near and far transfer of task-switching training. Developmental Science, 12(6), 978-990.

Karbach, J., \& Verhaeghen, P. (2014). Making working memory work: A meta-analysis of executive-control and working memory training in older adults. Psychological Science, 25(11), 2027-2037.

Katz, B., Jones, M. R., Shah, P., Buschkuehl, M., \& Jaeggi, S. M. (2016). Individual differences and motivational effects. In T. Strobach \& J. Karbach (Eds.), Cognitive training: An overview of features and applications (pp. 157-166). Springer International Publishing.
Khng, K. H., \& Lee, K. (2014). The relationship between stroop and stop-signal measures of inhibition in adolescents: Influences from variations in context and measure estimation. PLoS ONE, 9(7), Article e101356.

Kliegel, M., Ramuschkat, G., \& Martin, M. (2003). Exekutive Funktionen und prospektive Gedächtnisleistung im Alter: Eine differentielle Analyse von ereignis- und zeitbasierter prospektiver Gedächtnisleistung [Executive functions and prospective memory performance in old age: an analysis of event-based and time-based prospective memory]. Zeitschrift fur Gerontologie und Geriatrie, 36(1), 35-41.

Kray, J., \& Ferdinand, N. K. (2014). Task switching and aging. In J. A. Grange \& G. Houghton (Eds.), Task switching and cognitive control (pp. 350-371). Oxford University Press.

Kvavilashvili, L., \& Ellis, J.(1996). Varieties of intention: Some distinctions and classifications. In M. A. Brandimonte, G. O. Einstein, \& M. A. McDaniel (Eds.), Prospective memory: Theory and applications (pp. 23-52). Lawrence Erlbaum Associates.

Lah, A. (2020). Preverjanje veljavnosti pripomočka za merjenje kognitivnega nadzora [Validation of a new instrument for measuring cognitive control] [Master's thesis]. https://repozitorij.uni-lj.si/Dokument. php?id $=137548$ \&lang $=$ slv

Lustig, C., Shah, P., Seidler, R., \& Reuter-Lorenz, P. A. (2009). Aging, training, and the brain: A review and future directions. Neuropsychology Review, 19(4), 504-522.

Mangiafico, S. S. (2016). Summary and analysis of extension program evaluation in $R$, version 1.18.1. $\mathrm{R}$ companion. https://rcompanion.org/handbook/

Martin, M., Clare, L., Altgassen, A. M., Cameron, M. H., \& Zehnder, F. (2011). Cognition-based interventions for healthy older people and people with mild cognitive impairment. Cochrane database of systematic reviews, (1).

McDaniel, M. A., \& Einstein, G. O. (2000). Strategic and automatic processes in prospective memory retrieval: A multiprocess framework. Applied Cognitive Psychology, 14(7), S127-S144.

McDaniel, M. A., Glisky, E. L., Guynn, M. J., \& Routhieaux, B. C. (1999). Prospective memory: A neuropsychological study. Neuropsychology, 13(1), 103-110.

Melby-Lervåg, M., Redick, T. S., \& Hulme, C. (2016). Working memory training does not improve performance on measures of intelligence or other measures of "far transfer": Evidence from a meta-analytic review. Perspectives on Psychological Science, 11(4), 512-534.

Miyake, A., Friedman, N. P., Emerson, M. J., Witzki, A. H., Howerter, A., \& Wager, T. D. (2000). The unity and diversity of executive functions and their contributions to complex "frontal lobe" tasks: A latent variable analysis. Cognitive Psychology, 41(1), 49-100.

Monsell, S. (1996). Control of mental processes. In V. Bruce (Ed.), Unsolved mysteries of the mind: Tutorial essays in cognition (pp. 93-148). Taylor \& Francis. 
Mueller, S. T., \& Piper, B. J. (2014). The Psychology Experiment Building Language (PEBL) and PEBL Test Battery. Journal of Neuroscience Methods, 222, 250-259.

Pellicano, A., Lugli, L., Baroni, G., \& Nicoletti, R. (2009). The Simon Effect with conventional signals: A time-course analysis. Experimental Psychology, 56(4), 219-227.

Prosenik, U. (2019). Razvoj računalniške igre za izvedbo psiholoških testov in kognitivnega treninga [Development of a computer game for conducting psychological tests and cognitive training] [Master's thesis]. https:// repozitorij.uni-lj.si/Dokument.php?id=123259\&lang=slv

R Core Team (2019). R: A language and environment for statistical computing [computer software]. R Foundation for Statistical Computing, Vienna, Austria. https:// www.R-project.org/

Reynolds, C. R., \& MacNeill Horton, A. (2008). Assessing executive functions: A life-span perspective. Psychology in the Schools, 45(9), 875-892.

Rogers, R. D., \& Monsell, S. (1995). Costs of a predictable switch between simple cognitive tasks. Journal of Experimental Psychology: General, 124(2), 207-231.

Sala, G., \& Gobet, F. (2019). Cognitive training does not enhance general cognition. Trends in Cognitive Sciences, 23(1), 9-20.

Salthouse, T. A., Berish, D. E., \& Siedlecki, K. L. (2004). Construct validity and age sensitivity of prospective memory. Memory \& Cognition, 32(7), 1133-1148.

Schnitzspahn, K. M., Stahl, C., Zeintl, M., Kaller, C. P., \& Kliegel, M. (2013). The role of shifting, updating, and inhibition in prospective memory performance in young and older adults. Developmental Psychology, 49(8), 1544-1553.

Simmonds, D. J., Pekar, J. J., \& Mostofsky, S. H. (2008). Meta-analysis of Go/No-go tasks demonstrating that fMRI activation associated with response inhibition is task-dependent. Neuropsychologia, 46(1), 224-232.

Smith, E. E., \& Jonides, J. (1997). Working memory: A view from neuroimaging. Cognitive Psychology, 33(1), 5-42.

Stoet, G. (2010). PsyToolkit - A software package for programming psychological experiments using Linux. Behavior Research Methods, 42(4), 1096-1104.

Stoet, G. (2017). PsyToolkit: A novel web-based method for running online questionnaires and reaction-time experiments. Teaching of Psychology, 44(1), 24-31.

Thorell, L. B., Lindqvist, S., Bergman Nutley, S., Bohlin, G., \& Klingberg, T. (2009). Training and transfer effects of executive functions in preschool children. Developmental Science, 12(1), 106-113.

Unsworth, N., \& Spillers, G. J. (2010). Working memory capacity: Attention control, secondary memory, or both? A direct test of the dual-component model. Journal of Memory and Language, 62(4), 392-406.

Van der Molen, M. J., Van Luit, J. E. H., Van der Molen, M. W., Klugkist, I., \& Jongmans, M. J. (2010). Effectiveness of a computerised working memory training in adolescents with mild to borderline intellectual disabilities. Journal of Intellectual Disability Research, 54(5), 433-447.
Vargha, A., \& Delaney, H. D. (2000). A critique and improvement of the CL common language effect size statistics of McGraw and Wong. Journal of Educational and Behavioral Statistics, 25(2), 101-132.

White, H. A., \& Shah, P. (2006). Training attention-switching ability in adults with ADHD. Journal of Attention Disorders, 10(1), 44-53.

Wongupparaj, P., Kumari, V., \& Morris, R. G. (2015). The relation between a multicomponent working memory and intelligence: The roles of central executive and short-term storage functions. Intelligence, 53, 166-180.

Wylie, G. R., Javitt, D. C., \& Foxe, J. J. (2004). The role of response requirements in task switching: Dissolving the residue. NeuroReport, 15(6), 1079-1087.

Zuber, S., Ihle, A., Loaiza, V. M., Schnitzspahn, K. M., Stahl, C., Phillips, L. H., Kaller, C. P., \& Kliegel, M. (2019). Explaining age differences in working memory: The role of updating, inhibition, and shifting. Psychology \& Neuroscience, 12(2), 191-208.

Zuber, S., Kliegel, M., \& Ihle, A. (2016). An individual difference perspective on focal versus nonfocal prospective memory. Memory \& Cognition, 44(8), $1192-1203$. 


\section{Appendix}

\section{Table A1}

Medians (and MADs in parentheses) and Spearman correlation coefficients of the inhibition tasks results obtained in three groups in pretest and posttest measurements

\begin{tabular}{|c|c|c|c|c|c|c|c|c|c|}
\hline \multirow[b]{2}{*}{ Observed variables } & \multicolumn{3}{|c|}{$\begin{array}{l}\text { Inhibition training group } \\
\qquad(n=36)\end{array}$} & \multicolumn{3}{|c|}{$\begin{array}{l}\text { Shifting training group } \\
\qquad(n=35)\end{array}$} & \multicolumn{3}{|c|}{$\begin{array}{l}\text { Control group } \\
(n=36)\end{array}$} \\
\hline & Pretest & Posttest & $r_{\mathrm{S}}$ & Pretest & Posttest & $r_{\mathrm{S}}$ & Pretest & Posttest & $r_{\mathrm{S}}$ \\
\hline \multicolumn{10}{|l|}{ Accuracy } \\
\hline Simon task: Compatible & $.96(.02)$ & $.92(.05)$ & $.33^{*}$ & $.97(.02)$ & $.96(.02)$ & $.44^{* *}$ & -- & -- & -- \\
\hline Simon task: Incompatible & $.88(.06)$ & $.90(.07)$ & $.46^{* *}$ & $.90(.06)$ & $.92(.05)$ & .19 & -- & -- & -- \\
\hline PEBL Go/No-Go: No go & $.70(.20)$ & $.73(.20)$ & $.50^{* *}$ & $.80(.20)$ & $.80(.20)$ & $.44^{* *}$ & $1.00(.00)$ & $1.00(.00)$ & -.04 \\
\hline PEBL Go/No-Go: Go & $1.00(.00)$ & $1.00(.00)$ & $.68^{* * *}$ & $1.00(.00)$ & $1.00(.00)$ & .16 & $1.00(.00)$ & $1.00(.00)$ & $.58^{* * *}$ \\
\hline CCRacer Go/No-Go: No go & $.48(.25)$ & $.59(.34)$ & $.61^{* * *}$ & $.52(.27)$ & $.64(.36)$ & $.62^{* * *}$ & $.52(.27)$ & $.52(.31)$ & $.47^{* *}$ \\
\hline CCRacer Go/No-Go: Go & $1.00(.00)$ & $1.00(.00)$ & .05 & $1.00(.00)$ & $1.00(.00)$ & .17 & $1.00(.00)$ & $1.00(.00)$ & .11 \\
\hline \multicolumn{10}{|l|}{ Reaction times } \\
\hline Simon task: Compatible & $498(43)$ & $429(36)$ & $.56^{* * *}$ & $530(56)$ & $482(36)$ & $.71^{* * *}$ & -- & -- & -- \\
\hline Simon task: Incompatible & $536(44)$ & $441(36)$ & $.77^{* * *}$ & $574(53)$ & $512(33)$ & $.72^{* * *}$ & -- & -- & -- \\
\hline Simon task: Incompatibility cost & $40(29)$ & $11(15)$ & -.01 & $44(36)$ & $20(25)$ & $.52^{* *}$ & -- & -- & -- \\
\hline PEBL Go/No-Go: No go ${ }^{a}$ & $365(34)$ & $363(36)$ & $.40^{*}$ & $356(37)$ & $362(40)$ & $.72^{* * *}$ & $529(51)$ & $518(64)$ & $.67^{* * *}$ \\
\hline PEBL Go/No-Go: Go & $423(43)$ & $408(38)$ & $.75^{* * *}$ & $422(58)$ & $415(44)$ & $.78^{* * *}$ & $393(36)$ & $392(39)$ & $.69^{* * *}$ \\
\hline CCRacer Go/No-Go: No go & $363(31)$ & $376(41)$ & $.37^{*}$ & $353(49)$ & $365(33)$ & $.46^{* *}$ & $383(39)$ & $401(52)$ & $.57^{* * *}$ \\
\hline CCRacer Go/No-Go: Go & $418(44)$ & $423(39)$ & $.55^{* * *}$ & $425(65)$ & $410(47)$ & $.60^{* * *}$ & $436(46)$ & $440(49)$ & $.59^{* * *}$ \\
\hline
\end{tabular}

Notes. ${ }^{\text {an }}$ this tasks, RT from 31 participants were analysed for the pretest and the posttest (other participants had a 100-percent accuracy in the No go conditions).

${ }^{*} p<.05 .{ }^{* *} p<.01 .{ }^{* * *} p<.001$. 


\section{Table A2}

Medians (and MADs in parentheses) and Spearman correlation coefficients of the switching tasks results obtained in three groups in pretest and posttest measurements

\begin{tabular}{|c|c|c|c|c|c|c|c|c|c|}
\hline \multirow[b]{2}{*}{ Observed variables } & \multicolumn{3}{|c|}{$\begin{array}{l}\text { Inhibition training group } \\
\qquad(n=36)\end{array}$} & \multicolumn{3}{|c|}{$\begin{array}{l}\text { Shifting training group } \\
\qquad(n=35)\end{array}$} & \multicolumn{3}{|c|}{$\begin{array}{l}\text { Control group } \\
(n=36)\end{array}$} \\
\hline & Pretest & Posttest & $r_{\mathrm{S}}$ & Pretest & Posttest & $r_{\mathrm{S}}$ & Pretest & Posttest & $r_{\mathrm{S}}$ \\
\hline \multicolumn{10}{|l|}{ Accuracy } \\
\hline \multicolumn{10}{|l|}{ Task Switching Paradigm } \\
\hline Letters only & $.94(.03)$ & $.96(.03)$ & .21 & $.96(.03)$ & $.96(.03)$ & .06 & $.95(.04)$ & $.95(.04)$ & .19 \\
\hline Numbers only & $.94(.03)$ & $.92(.06)$ & $.41^{*}$ & $.96(.03)$ & $.96(.06)$ & -.06 & $.95(.04)$ & $.92(.04)$ & $.56^{* *}$ \\
\hline Mixed, switch & $.96(.06)$ & $.92(.06)$ & $.42^{*}$ & $.96(.03)$ & $.96(.03)$ & $.41^{*}$ & $.92(.04)$ & $.94(.06)$ & .03 \\
\hline Mixed, no switch & $.98(.03)$ & $.96(.03)$ & $.42^{*}$ & $.98(.03)$ & $.94(.06)$ & -.22 & $.98(.04)$ & $.98(.04)$ & .22 \\
\hline \multicolumn{10}{|l|}{ CCRacer Crossroads } \\
\hline Odd-even only & $1.00(.00)$ & $1.00(.00)$ & .20 & $.96(.06)$ & $1.00(.00)$ & .31 & $.96(.06)$ & $1.00(.00)$ & $.52^{* * *}$ \\
\hline Smaller-larger only & $.96(.05)$ & $1.00(.00)$ & -.20 & $.93(.05)$ & $1.00(.00)$ & .32 & $.92(.06)$ & $.96(.05)$ & $.42^{* *}$ \\
\hline Mixed & $.98(.03)$ & $1.00(.00)$ & .12 & $.98(.03)$ & $1.00(.00)$ & .33 & $.92(.08)$ & $.96(.06)$ & $.69^{* * *}$ \\
\hline \multicolumn{10}{|l|}{ Reaction times } \\
\hline \multicolumn{10}{|l|}{ Task Switching Paradigm } \\
\hline Letters only (1) & $639(55)$ & $589(63)$ & $.47^{* *}$ & $673(102)$ & $474(59)$ & $.67^{* * *}$ & $655(75)$ & $606(58)$ & $.45^{* *}$ \\
\hline Numbers only (2) & $633(54)$ & $584(56)$ & $.85^{* * *}$ & $691(71)$ & $506(61)$ & $.65^{* * *}$ & $650(70)$ & $620(61)$ & $.38^{* *}$ \\
\hline Mixed, switch (3) & 975 (192) & $740(130)$ & $.81^{* * *}$ & $1141(188)$ & $489(59)$ & $.36^{*}$ & $1106(225)$ & $908(184)$ & $.41^{*}$ \\
\hline Mixed, no switch (4) & $666(118)$ & $571(59)$ & $.79^{* * *}$ & $694(86)$ & $468(47)$ & .30 & $701(116)$ & $631(94)$ & $.55^{* * *}$ \\
\hline Switching cost $(3-(1+2) / 2)$ & $337(156)$ & $161(102)$ & $.66^{* * *}$ & $473(185)$ & $8(25)$ & .03 & $464(210)$ & 293 (209) & $.44^{* *}$ \\
\hline \multicolumn{10}{|l|}{ CCRacer Crossroads } \\
\hline Odd-even only (5) & $1050(126)$ & $894(106)$ & $.47^{* *}$ & $1208(172)$ & $926(107)$ & $.50^{* *}$ & $1096(129)$ & $880(98)$ & $.75^{* * *}$ \\
\hline Smaller-larger only (6) & $1128(142)$ & $957(142)$ & $.35^{*}$ & $1244(192)$ & $1043(145)$ & $.51^{* *}$ & $1211(145)$ & $964(148)$ & $.58^{* * *}$ \\
\hline Mixed (7) & $1147(127)$ & $1007(90)$ & $.76^{* * *}$ & $1273(132)$ & $1051(120)$ & $.51^{* *}$ & $1162(133)$ & $1062(157)$ & $.63^{* * *}$ \\
\hline Switching cost $(7-(5+6) / 2)$ & $50(87)$ & $107(110)$ & .29 & $56(117)$ & $64(90)$ & .05 & $35(98)$ & $112(83)$ & .19 \\
\hline \multicolumn{10}{|l|}{ PEBL Switcher } \\
\hline Two rules (8) & $1692(172)$ & 1499 (194) & $.71^{* * *}$ & $1753(193)$ & $1438(259)$ & $.68^{* * *}$ & -- & -- & -- \\
\hline Three rules - consistent (9) & $1654(279)$ & $1486(215)$ & $.79^{* * *}$ & $1878(332)$ & $1513(289)$ & $.81^{* * *}$ & -- & -- & -- \\
\hline Three rules - inconsistent (10) & $1771(218)$ & 1688 (179) & $.62^{* * *}$ & $1855(240)$ & $1660(205)$ & $.74^{* * *}$ & -- & -- & -- \\
\hline Switching cost $(9-8)$ & $-4(118)$ & $3(165)$ & .13 & $95(142)$ & $86(203)$ & .25 & -- & -- & -- \\
\hline Switching cost $(10-9)$ & $114(155)$ & $252(205)$ & .17 & $17(329)$ & $202(225)$ & .25 & -- & -- & -- \\
\hline
\end{tabular}

${ }^{*} p<.05 .{ }^{* *} p<.01 .{ }^{* * *} p<.001$.

\section{Table A3}

Medians (and MADs in parentheses) and Spearman correlation coefficients of the results of working and prospective memory tasks in two training groups in pretest and posttest measurements

\begin{tabular}{|c|c|c|c|c|c|c|}
\hline \multirow[b]{2}{*}{ Observed variables } & \multicolumn{3}{|c|}{$\begin{array}{l}\text { Inhibition training group } \\
\qquad(n=36)\end{array}$} & \multicolumn{3}{|c|}{$\begin{array}{l}\text { Shifting training group } \\
\qquad(n=35)\end{array}$} \\
\hline & Pretest & Posttest & $r_{\mathrm{S}}$ & Pretest & Posttest & $r_{\mathrm{S}}$ \\
\hline WM: Equation solving accuracy & $.98(.02)$ & $.97(.02)$ & $.49^{* *}$ & $.98(.02)$ & $.97(.02)$ & .20 \\
\hline WM: Maximum number of letters remembered & $8(1.5)$ & $8(1.5)$ & $.41^{*}$ & $8(1.5)$ & $8(1.5)$ & .22 \\
\hline Event-based PM: Event detection accuracy & $.73(.26)$ & $.90(.11)$ & $.68^{* * *}$ & $.73(.26)$ & $.87(.14)$ & $.76^{* * *}$ \\
\hline Time-based PM: Number of time checks & $11(7.4)$ & $12(7.5)$ & $.74^{* * *}$ & $10(7.4)$ & $11(5.9)$ & $.64^{* * *}$ \\
\hline Time-based PM: Number of correct time responses & $1(1.5)$ & $1(1.5)$ & $.61^{* * *}$ & $1(1.5)$ & $1(1.5)$ & $.48^{* *}$ \\
\hline
\end{tabular}

${ }^{*} p<.05 .{ }^{* *} p<.01 .{ }^{* * *} p<.001$. 